\title{
Ammonium and nitrate in soil and upland rice yield as affected by cover crops and their desiccation time
}

\author{
Adriano Stephan Nascente ${ }^{(1)}$, Carlos Alexandre Costa Crusciol(2) and Tarcísio Cobucci ${ }^{(1)}$
}

\begin{abstract}
(1)Embrapa Arroz e Feijão, Rodovia GO-462, Km 12, Zona Rural, Caixa Postal 179, CEP 75375-000 Santo Antônio de Goiás, GO. E-mail: adriano.nascente@embrapa.br, tarcisio.cobucci@embrapa.br ${ }^{(2)}$ Universidade Estadual Paulista, Faculdade de Ciências Agronômicas, Departamento de Produção Vegetal, Campus de Botucatu, Caixa Postal 237, CEP 18603-970 Botucatu, SP. E-mail: crusciol@fca.unesp.br
\end{abstract}

\begin{abstract}
The objective of this work was to evaluate the effect of cover crops and their desiccation times on upland rice yield and on the levels of nitrate and ammonium in a no-tillage soil. The experiment was carried out in a randomized blocks, with split plots and three replicates. Cover crops (plots) were sowed in the offseason (March 2009). In November 2009, at 30, 20, 10 and 0 days before rice sowing (split plots), herbicide was applied on the cover crops (fallow, Panicum maximum, Urochloa ruziziensis, U. brizantha and millet). Straw and soil were sampled $(0-10 \mathrm{~cm})$ at the sowing day, and after 7, 14, 21, 28 and 35 days. Straws from millet and fallow were degraded more rapidly and provided the lowest level of nitrate in the soil. Urochloa ruziziensis, $U$. brizantha and $P$. maximum produced higher amounts of dry matter, and provided the highest levels of nitrate in the soil. Millet provides the lowest nitrate/ammonium ratio and the highest upland rice yield. Desiccations carried out at 30 and 20 days before sowing had the largest levels of nitrate in the soil at the sowing date. Nitrogen content and forms in the soil are affected by cover crops and their desiccation times.
\end{abstract}

Index terms: Oryza sativa, Panicum maximum, Urochloa brizantha, Urochloa ruziziensis, millet, nitrogen.

\section{Amônio e nitrato no solo e produtividade do arroz de terras altas influenciados por plantas de cobertura e suas épocas de dessecação}

\begin{abstract}
Resumo - O objetivo deste trabalho foi avaliar o efeito de plantas de cobertura e de suas épocas de dessecação na produtividade do arroz de terras altas e nos níveis de nitrato e amônio de solo em plantio direto. O experimento foi realizado em blocos ao acaso, com parcelas subdivididas e três repetições. As plantas de cobertura (parcelas) foram semeadas na entressafra (março de 2009). Em novembro de 2009, aos 30, 20, 10 e 0 dias antes da semeadura do arroz (parcelas subdivididas), realizou-se o manejo químico das plantas de cobertura (pousio, Panicum maximum, Urochloa ruziziensis, U. brizantha e milheto). As palhadas e o solo (camada 0-10 cm) foram amostrados no dia da semeadura do arroz e após 7, 14, 21, 28 e 35 dias. As palhas do milheto e do pousio degradaram-se mais rapidamente e proporcionaram os menores níveis de nitrato ao solo. Urochloa ruziziensis, U. brizantha e P. maximum produziram mais matéria seca e proporcionaram os maiores níveis de nitrato no solo. $\mathrm{O}$ milheto proporciona menor relação nitrato/amônio no solo e maior produtividade do arroz. A dessecação aos 30 e 20 dias da semeadura do arroz proporciona os maiores níveis de nitrato no solo, na data de plantio. O conteúdo e a forma do nitrogênio no solo são afetados pelas plantas de cobertura e por suas épocas de dessecação.
\end{abstract}

Termos para indexação: Oryza sativa, Panicum maximum, Urochloa brizantha, Urochloa ruziziensis, milheto, nitrogênio.

\section{Introduction}

Rice is grown mostly on irrigated lands (Prasad, 2011). However, water availability is decreasing due to the competing demands of industry and population. Therefore, alternatives are sought to allow a greater water use efficiency (Qu et al., 2008). Some alternatives include growing rice under aerobic conditions, in no-tillage system (Tao et al., 2006).

An essential factor to be considered in no-tillage system (NTS) is the decomposition of cover crops.
Straws on the soil surface contribute to reduce nutrient loss and help to increase the levels of soil organic matter (Boer et al., 2007; Torres et al., 2008; Pacheco et al., 2011). However, the time interval between cover crop desiccation and sowing of cash crops is important (Nascente \& Crusciol, 2012; Nascente et al., 2012). The ideal timing should be set according to cover crop traits, cultivation density, developmental stage, and the nature and level of herbicide used (Dabney et al., 2001). An appropriate desiccation time can provide, at the right time, the

Pesq. agropec. bras., Brasília, v.47, n.12, p.1699-1706, dez. 2012 
necessary nutrients for following crops (D'Andrea et al., 2004; Kliemann et al., 2006).

Nitrogen is one of the most important nutrients to plant development (Torres et al., 2005; Fageria \& Moreira, 2011; Nascente et al., 2011; Araújo et al., 2012). Fast release of $\mathrm{N}$ from cover crop residues, before the onset of expressive demand from the cash crop, can lead to $\mathrm{N}_{-} \mathrm{NO}_{3}^{-}$loss through leaching or denitrification (D'Andrea et al., 2004; Torres et al., 2005; Pacheco et al., 2011). However, if $\mathrm{N}$ release from decomposing residues is delayed, $\mathrm{N}$ deficiency can occur (Kliemann et al., 2006; Torres et al., 2008). Moreover, during straw decomposition, ammonium is released to the soil and, in aerobic conditions, it quickly becomes nitrate. Therefore, $\mathrm{N}-\mathrm{NO}_{3}^{-}$predominates in the upland rice cultivation (D'Andréa et al., 2004). These authors stated that no-tillage system favors the availability of $\mathrm{N}^{-\mathrm{NO}_{3}^{-}}$ compared to the conventional tillage due to higher storage of moisture, nutrients, and organic matter in the soil, which benefit nitrifying bacteria.

Most plants absorb both $\mathrm{NO}_{3}{ }^{-}$and $\mathrm{NH}_{4}{ }^{+}$mineral forms of $\mathrm{N}$ (Poletto et al., 2011). However, Lin et al. (2005), Li et al. (2007), Holzschuh et al. (2009), Poletto et al. (2011) and Araújo et al. (2012) showed that upland rice perform best when $\mathrm{NH}_{4}{ }^{+}$is predominant during the initial development of plants. However, these authors warn that the exclusive availability of ammonium can be detrimental for rice plants, and ranges around to $50-75 \%$ nitrate and $50-25 \%$ ammonium provide better upland rice performance. Therefore, cover crops that would provide larger amounts of $\mathrm{NH}_{4}^{+}$ or lower nitrate/ammonium ratio, at the early development of upland rice, can benefit this crop in NTS.

For the effective incorporation of cover crops into the agricultural production system, the herbicide application timing is very important (Dabney et al., 2001). Moreover, such an understanding will determine the amount of additional fertilizer needed and can reduce the production cost (Torres et al., 2005; Kliemann et al., 2006).

The objective of this work was to evaluate the effect of cover crops and their desiccation times on the levels of nitrate and ammonium in a no-tillage soil and on upland rice yield.

\section{Material and Methods}

The field experiment was carried out in Santo Antônio de Goiás, GO, Brazil $\left(16^{\circ} 27^{\prime} \mathrm{S}, 49^{\circ} 17^{\prime} \mathrm{W}\right.$ and $823 \mathrm{~m}$ altitude). The climate is Aw, according to the Köppen classification with two well defined seasons: the dry season, from May to September (winter), and the rainy season, from October to April (summer). The annual mean rainfall is between $1,500-1,700 \mathrm{~mm}$. Local annual mean temperature is $22.7^{\circ} \mathrm{C}$, varying annually from $14.2^{\circ} \mathrm{C}$ to $34.8^{\circ} \mathrm{C}$.

The soil is classified as Rhodic Ferralsol (Food and Agriculture Organization of the United Nations, 1998), with a gently undulating topography. Soil texture is clayey $\left(540 \mathrm{~g} \mathrm{~kg}^{-1}\right.$ clay, $110 \mathrm{~g} \mathrm{~kg}^{-1}$ silt, and $350 \mathrm{~g} \mathrm{~kg}^{-1}$ sand). For soil analysis, 48 samples were collected from 0-5, 5-10 and 10-20-cm soil depths before deployment of the experiment. Soil chemical characterization for the respective layers was: $\mathrm{pH}$ (water), 5.7, 5.7 and 5.5; total soil organic matter, 23.0, 17.5 and $13.5 \mathrm{~g} \mathrm{dm}^{-3}$; $\mathrm{P}, 14.6,15.4$ and $15.9 \mathrm{mg} \mathrm{dm}^{-3} ; \mathrm{K}, 191.9,144.9$ and $107.7 \mathrm{mg} \mathrm{dm}^{-3}$; Ca, 2.8, 2.1 and $1.8 \mathrm{cmol}_{\mathrm{c}} \mathrm{dm}^{-3}$; $\mathrm{Mg}, 1.4,0.8$ and $0.5 \mathrm{cmol}_{\mathrm{c}} \mathrm{dm}^{-3} ; \mathrm{Cu}, 1.5,1.8$ and $1.9 \mathrm{mg} \mathrm{dm}^{-3}$; Zn, 4.9, 4.4 and $4.0 \mathrm{dm}^{-3}$; Fe, 30.6, 32.2 and $32.3 \mathrm{dm}^{-3}$; and $\mathrm{Mn}, 25.2,20.9$ and $18.4 \mathrm{mg} \mathrm{dm}^{-3}$. Phosphorus and $\mathrm{K}$ were extracted by Mehlich 1 extracting solution, from which $\mathrm{P}$ was determined colorimetrically and $\mathrm{K}$ by flame photometry. $\mathrm{Ca}, \mathrm{Mg}$, and $\mathrm{Al}$ were extracted with $1 \mathrm{~mol} \mathrm{~L}^{-1} \mathrm{KCl}$. Aluminum was determined by titration with $\mathrm{NaOH}$, and $\mathrm{Ca}$ and $\mathrm{Mg}$ by titration with EDTA. Micronutrients were determined on a portion of the extract for P by atomic absorption spectrophotometry.

The research was carried out in an area that had been under NTS for eight years (2001/2002-2008/2009), in rotations with corn (2001, 2003, 2005 and 2007), soybean (2002, 2004 and 2006) and upland rice (2008) in the summer, and fallow in the winter.

A randomized block experimental design was used with a split-plot arrangement and three replicates. The plots $(6 \times 40 \mathrm{~m})$ consisted of five cover crops, and the split plots $(6 \times 10 \mathrm{~m})$ consisted of four desiccation times (30, 20, 10 and 0 days before upland rice sowing). There was a $1 \mathrm{~m}$ wide alley between each split plot. Cover crops used were: Panicum maximum; Urochloa ruziziensis (syn. Brachiaria ruziziensis); Urochloa brizantha (syn. Brachiaria brizantha); millet (Pennisetum glaucum); and fallow, composed of spontaneous vegetation, predominantly Bidens pilosa, 
Commelina benghalensis, Conyza bonariensis and Cenchrus echinatus.

Cover crops were sowed in the off season (March 2009), in rows spaced at $0.20 \mathrm{~m}$, using a mechanical planter set to distribute $10 \mathrm{~kg} \mathrm{ha}^{-1}$ of seeds with at least $30 \%$ germination, without fertilizer. Cover crop desiccations were done with glyphosate application at $1.8 \mathrm{~kg} \mathrm{ha}^{-1}$ acid equivalent. In the following growing season (November 2009), the of upland rice (Oryza sativa) cultivar BRS Sertaneja was sowed in rows spaced at $0.35 \mathrm{~m}$, with a population of 60 plants $\mathrm{m}^{-1}$. Sowing-fertilization was $20 \mathrm{~kg} \mathrm{ha}^{-1} \mathrm{~N}$ as urea, $120 \mathrm{~kg} \mathrm{ha}^{-1} \mathrm{P}_{2} \mathrm{O}_{5}$ as triple superphosphate, and $60 \mathrm{~kg} \mathrm{ha}^{-1} \mathrm{~K}_{2} \mathrm{O}$ as potassium chloride, plus $20 \mathrm{~kg} \mathrm{ha}^{-1}$ $\mathrm{N}$ as urea, one day and 45 days after upland rice was seeded.

For assessing of straw degradation, cover crops were sampled at 0, 7, 14, 21, 28 and 35 days after rice sowing. At each time, samples were collected from a 1.0x1.0 m area, randomly selected in each split plot. Collected plant materials were placed in paper bags, dried in a forced-ventilation oven at $65^{\circ} \mathrm{C}$, and weighed. Dry matter measure was converted to megagrams per hectare. Data were applied to an exponential mathematical model, proposed by Thomas \& Asakawa (1993) and used by Pacheco et al. (2011), using the equation $\mathrm{y}=\mathrm{y}_{0} \times \exp ^{(-\mathrm{kt})}$, in which: $\mathrm{y}$ is the fraction of the initial residue existing at time $t ; y_{0}$ is the proportion of potentially decomposable residue; and $\mathrm{k}$ is the constant for residue decomposition. With the $k$ value, the half-life time ( $\left.T^{1 / 2}\right)$ was calculated for the remained straw of each cover crop, using the equation proposed by Paul \& Clark (1989) as $\mathrm{T}^{1} / 2=0,693 / \mathrm{k}$.

For $\mathrm{C}$ and $\mathrm{N}$ analyses in cover crops, each dried sample was milled (Willey type mill with a $2 \mathrm{~mm}$ mesh), and between four and five milligrams were packed in tin capsules. Levels of $\mathrm{C}$ and $\mathrm{N}$ were determined by dry combustion, using an elemental analyzer CHNS/O 2400 Series II (Perkin Elmer, Walthan, MA, USA).

Soil sampling was carried out, with an auger-like tool, 30 days after the first desiccation (upland rice sowing day) of cover crops, and at 7, 14, 21, 28 and 35 days after sowing (Figure 1). Eight subsamples were collected and homogenized manually for each composite sample from each split plot, at $0-10 \mathrm{~cm}$ soil depth. The samples were then wrapped in plastic bags, labeled, kept in a cooler with ice, and sent to laboratory for analysis.
Analyses of mineral $\mathrm{N}$ were held at the same day of soil sampling. From each soil sample, an aliquot of 20 grams of soil was taken and mixed with $60 \mathrm{~mL}$ extraction solution $\mathrm{KCl}$ at $2 \mathrm{~mol} \mathrm{~L}^{-1}$ (Bremner, 1965). After shaking for an hour, solid material decanted, and the supernatant was filtered using filter paper. This supernatant was used to quantify the levels of nitrate and ammonium.

The method proposed by Griess (1879) was used to indirectly quantify nitrate - in the form of nitrite ion - after reaction with sulphanilamide and $\mathrm{N}-\alpha$-naftiletilenodiamine. Ammonium was determined according to the methodology of Krom (1980). Both $\mathrm{N}_{-} \mathrm{NH}_{4}^{+}$and $\mathrm{N}^{-\mathrm{NO}_{3}}$ were determined by spectrophotometry associated to a flow-injection analysis, following the methodology used by Gine et al. (1980). The concentration of $\mathrm{NH}_{4}{ }^{+}$and $\mathrm{NO}_{3}^{-}$ in the soil were expressed as milligrams per kilogram of dry soil.

Manual harvest of upland rice was performed when about $90 \%$ of panicles had grains of typical mature coloration. Grain yield was measured (weight of unhulled grains collected at the three central five-meter-rows, in each split plot, eliminating 2.5-meter on each side of the split plots from the usable areas), and the moisture content was corrected to $130 \mathrm{~g} \mathrm{~kg}^{-1}$ wet basis.

Analysis of variance and LSD mean separation test were applied to data, using the statistical software package SAS. Polynomial regression analysis was done for upland rice yield, and for mineral $\mathrm{N}$ data for each straw type, depending on time of data collection and desiccation time.

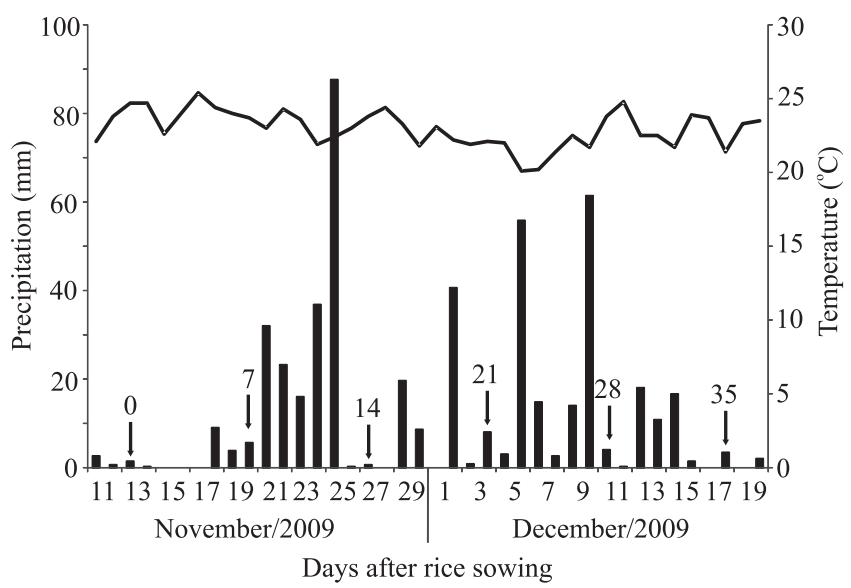

Figure 1. Precipitation and temperature at the experimental site during the first six weeks of rice growth. Arrows show sampling dates, and the labels represent the number of days after sowing, when the samples were taken. 


\section{Results and Discussions}

Straw productivity and half-life varied according to the cover crop (Table 1). Urochloa ruziziensis produced the highest amount of dry matter $\left(12.55 \mathrm{Mg} \mathrm{ha}^{-1}\right)$, and differed from the other cover crops. Urochloa brizantha (9.44 $\mathrm{Mg} \mathrm{ha}^{-1}$ ) and P. maximum (6.98 $\left.\mathrm{Mg} \mathrm{ha}^{-1}\right)$ did not significantly differ from each other; however, they differed from fallow (4.05 $\mathrm{Mg} \mathrm{ha}^{-1}$ ) and millet (3.90 $\mathrm{Mg} \mathrm{ha}^{-1}$ ). When sowed in the beginning of the growing season, millet production can be as high as $15 \mathrm{Mg} \mathrm{ha}^{-1}$, however, when sowed in the off season, its dry matter production is about $4-5 \mathrm{Mg} \mathrm{ha}^{-1}$ (Boer et al., 2007). According to Torres et al. (2008), Pacheco et al. (2011), Nascente \& Crusciol (2012) and Nascente et al. (2012), perennial forages such as U. ruziziensis, $U$. brizantha, and $P$. maximum can produce high amounts of dry matter.

Regarding half-life, millet (42 days) and fallow (44 days) had the lowest values. Panicum maximum (64 days), U. ruziziensis (65 days) and U. brizatha (66 days) had the highest half-lifes. These perennial forages have a great potential for a longer residence time on soil surface, due to their high $\mathrm{C} / \mathrm{N}$ ratio (Table 2), which delays straw decomposition (Pacheco et al., 2011). Evaluation of half-life time is important, since the faster is the straw decomposition; the greater is the rate of nutrient release (Kliemann et al., 2006; Torres et al., 2008).

The faster straw degradation observed in millet and fallow can be explained by their lower $\mathrm{C} / \mathrm{N}$ ratio. However, $\mathrm{N}$ availability and straw degradation rates reduces with time (Pacheco et al., 2011).

Table 1. Regression analysis of cover crop degradation, dry matter production, decomposition rate $(\mathrm{k})$, time of half-life $\left(\mathrm{T}^{1 / 2} /\right)^{(1)}$, and $\mathrm{N}$ concentration in the cover crop straw, at rice sowing day ${ }^{(2)}$.

\begin{tabular}{lcccccc}
\hline Cover crop & Regression & $\mathrm{R}^{2}$ & $\begin{array}{c}\text { Dry } \\
\text { matter }\end{array}$ & $\mathrm{k}$ & $\begin{array}{c}\mathrm{T}^{1} / 2 \\
(\text { days })\end{array}$ & $\begin{array}{c}\mathrm{N} \\
\left(\mathrm{g} \mathrm{kg}^{-1}\right)\end{array}$ \\
\hline Fallow & $\mathrm{y}=4.05 \mathrm{e}^{-0.0158 \mathrm{t}}$ & $0.84^{* *}$ & $4.05 \mathrm{c}$ & 0.018 & $44 \mathrm{~b}$ & $10.30 \mathrm{~b}$ \\
Panicum maximum & $\mathrm{y}=6.98 \mathrm{e}^{-0.0109 \mathrm{t}}$ & $0.81^{* *}$ & $6.98 \mathrm{~b}$ & 0.0109 & $64 \mathrm{a}$ & $13.65 \mathrm{a}$ \\
Urochloa ruziziensis & $\mathrm{y}=12.55 \mathrm{e}^{-0.0106 \mathrm{t}}$ & $0.61^{* *}$ & $12.55 \mathrm{a}$ & 0.0106 & $65 \mathrm{a}$ & $14.32 \mathrm{a}$ \\
Urochloa brizantha & $\mathrm{y}=9.44 \mathrm{e}^{-0.0105 t}$ & $0.73^{* *}$ & $9.44 \mathrm{~b}$ & 0.0105 & $66 \mathrm{a}$ & $14.64 \mathrm{a}$ \\
Millet & $\mathrm{y}=3.90 \mathrm{e}^{-0.0164 t}$ & $0.88^{* *}$ & $3.90 \mathrm{c}$ & 0.0164 & $42 \mathrm{~b}$ & $11.71 \mathrm{~b}$ \\
\hline
\end{tabular}

${ }^{(1)}$ Estimated by $\mathrm{y}=\mathrm{y}_{0} \times \exp ^{(-\mathrm{kt})}$. ${ }^{(2)}$ Means followed by equal letters do no differ by LSD test, at $5 \%$ probability.**Significant at $1 \%$ probability.
There were significant interactions between cover crops and sampling day $(\mathrm{p}<0.05)$, cover crops and herbicide timing and sampling day and herbicide timing ( $\mathrm{p}<0.01$ ), as to the nitrate levels in the soil. For the ammonium levels, only the main effect of sampling day was significant. For nitrate/ammonium ratios, there was a significant interaction between cover crops and sampling days. For grain yield, only the main effects of cover crops and herbicide timing were significant.

Urea application increased nitrate levels in the soil at 1 and 7 days after sowing, in all split-plots (Table 2). Pacheco (2009), working in the same soil with rice crops under $U$. ruziziensis, U. brizantha, P. glaucum and fallow, found increased nitrate levels in the soil after application of $60 \mathrm{~kg} \mathrm{ha}^{-1} \mathrm{~N}$ at 45 days after rice emergence. Urea is hydrolyzed in two or three days by the action of urease, producing ammonium carbonate and, then, $\mathrm{NH}_{3}, \mathrm{CO}_{2}$ and water. Ammonia $\left(\mathrm{NH}_{3}\right)$ formation depends on $\mathrm{pH}$ and soil moisture. Increasing amounts of this molecule is converted to $\mathrm{NH}_{4}{ }^{+}$in lower $\mathrm{pH}$. Ammonium $\left(\mathrm{NH}_{4}^{+}\right)$is rapidly metabolized from ammonium to nitrate in aerobic environment, in a process called nitrification. As the second sampling was done six days after urea application, it was possibly too late to measure any ammonium left before its change to nitrate (Fageria \& Moreira, 2011).

Soil nitrate levels were lower under millet and fallow in almost all evaluations, but mainly at the first, third and sixth weeks of rice development (Table 2). This is possibly due to the low concentrations of $\mathrm{N}$ in the leaves of millet and fallow. Panicum maximum, $U$. ruziziensis and $U$. brizantha provided higher amounts of nitrate in the soil, in almost all samplings. These species also have higher concentration of $\mathrm{N}$ in their leaves. According to D'Andréa et al. (2004), Kliemann et al. (2006), Boer et al. (2007) and Pacheco et al. (2011), a more intense nutrient cycling is expected with high dry matter production. Therefore, the high straw productivity of $P$. maximum, $U$. ruziziensis and $U$. brizantha, multiplied by their $\mathrm{N}$ contents in the straw, provided higher inputs of $\mathrm{N}$ to the soil than millet and fallow. This may have reflected in the $\mathrm{NO}_{3}^{-}$ levels observed in these treatments.

After the third sampling (14 days), a sharp drop in soil nitrate levels was observed (Table 2). This occurred in part because of the more intense root development (Fageria \& Moreira, 2011). It also can be a consequence of the large amount of rainfall in the experimental area 
(Figure 1). One day before the fourth sampling, it rained $40.6 \mathrm{~mm}$; between the fifth and sixth samplings, rainfall accumulated $160 \mathrm{~mm}$, from which $61.40 \mathrm{~mm}$ fell down in the night previous to the fifth sampling. According to Carneiro et al. (2009), nitrate is easily leachable, and leaching is directly related to the volume of precipitated water.

The interaction between desiccation times and sampling dates showed that the firsts sampling dates had a tendency of presenting higher soil nitrate concentrations with earlier desiccation times. However, this tendency was reversedin the last two sampling dates, with the biggest amount of soil nitrate found when desiccation occurred in the same day of sowing (Table 3). However, the amounts of soil nitrate in these last sampling dates were very small compared to the ones observed in the earlier samplings. Therefore, in order to supply the following crop with nitrate, desiccation should be done between 20 and 30 days before crop sowing, since it would provide higher soil contents of this nutrient up to 21 days after rice sowing. According to Grisso et al. (2009), the N amount effectively used, after cover crops desiccation, depends on the timing between their decomposition rate and cash crop demand.

Accordingly to the interaction between desiccation time and cover crops (Figure 2), soil nitrate fitted a quadratic regression under fallow and millet, with increasing levels of soil nitrate as the desiccation time approached the sowing date, up to the 10 days before sowing. Under P. maximum, U. ruziziensis and $U$. brizantha, data fitted a linear regression, with higher nitrate levels at earlier desiccation time.

Soil ammonium levels did not interact cover crops. Ammonium quickly changes to nitrate in aerobic environments, and it normally does not accumulate in the soil (Pacheco et al., 2011). Therefore, data were very similar in all sampling dates, for all cover crops, especially at 7, 28 and 35 DAS (Table 2). At sowing, millet provided the highest ammonium level

Table 2. Relation $\mathrm{C}: \mathrm{N}$, soil nitrate level, soil ammonium level and nitrate/ammonium ratio at $0-10 \mathrm{~cm}$ soil depth, as a function of the cover crops and sampling dates (days after sowing, DAS) ${ }^{(1)}$.

\begin{tabular}{|c|c|c|c|c|c|c|}
\hline \multirow[t]{2}{*}{ Cover crop } & \multicolumn{6}{|c|}{ Sampling dates (DAS) } \\
\hline & 0 & 7 & 14 & 21 & 28 & 35 \\
\hline & \multicolumn{6}{|c|}{$\mathrm{C}: \mathrm{N}$ relation } \\
\hline Fallow & 32 & 32 & 33 & 35 & 37 & 39 \\
\hline Panicum maximum & 28 & 28 & 33 & 39 & 41 & 47 \\
\hline Urochloa ruziziensis & 31 & 33 & 35 & 37 & 43 & 50 \\
\hline Urochloa brizantha & 33 & 36 & 37 & 39 & 42 & 49 \\
\hline$\underline{\text { Millet }}$ & 26 & 26 & 28 & 32 & 38 & 39 \\
\hline \multirow[t]{2}{*}{ Mean } & $43.72 \mathrm{C}$ & $109.10 \mathrm{~A}$ & $52.43 \mathrm{~B}$ & $25.52 \mathrm{D}$ & $3.19 \mathrm{E}$ & $6.13 \mathrm{E}$ \\
\hline & \multicolumn{6}{|c|}{ Soil nitrate level $\left(\mathrm{mg} \mathrm{kg}^{-1}\right)$} \\
\hline Fallow & $39.03 b$ & $84.39 b$ & $40.74 b$ & $26.25 b$ & $2.52 \mathrm{~cd}$ & $4.94 \mathrm{~b}$ \\
\hline P. maximum & $47.92 \mathrm{a}$ & $117.84 \mathrm{a}$ & $51.67 \mathrm{ab}$ & $36.41 \mathrm{a}$ & $3.16 \mathrm{bc}$ & $7.10 \mathrm{a}$ \\
\hline U. ruziziensis & $51.18 \mathrm{a}$ & $129.04 \mathrm{a}$ & $62.84 \mathrm{a}$ & $29.20 \mathrm{ab}$ & $3.96 \mathrm{ab}$ & $7.33 \mathrm{a}$ \\
\hline U. brizantha & 43.43ab & $132.34 \mathrm{a}$ & $66.37 \mathrm{a}$ & $19.91 b c$ & $4.43 \mathrm{a}$ & $7.03 \mathrm{a}$ \\
\hline Millet & $37.04 \mathrm{~b}$ & $81.90 \mathrm{~b}$ & $40.53 b$ & $15.84 \mathrm{c}$ & $1.87 \mathrm{~d}$ & $4.24 \mathrm{~b}$ \\
\hline \multirow[t]{2}{*}{ Mean } & $43.72 \mathrm{C}$ & $109.10 \mathrm{~A}$ & $52.43 \mathrm{~B}$ & $25.52 \mathrm{D}$ & $3.19 \mathrm{E}$ & $6.13 \mathrm{E}$ \\
\hline & \multicolumn{6}{|c|}{ Soil ammonium level $\left(\mathrm{mg} \mathrm{kg}^{-1}\right)$} \\
\hline Fallow & $2.83 \mathrm{~b}$ & $36.37 \mathrm{a}$ & $10.05 \mathrm{ab}$ & $6.54 \mathrm{~b}$ & $6.96 a$ & $9.24 \mathrm{a}$ \\
\hline P. maximum & $3.47 \mathrm{ab}$ & $45.66 \mathrm{a}$ & $11.18 \mathrm{a}$ & $6.75 b$ & $6.75 \mathrm{a}$ & $10.82 \mathrm{a}$ \\
\hline U. ruziziensis & $2.70 \mathrm{~b}$ & $38.00 \mathrm{a}$ & $5.54 b$ & $8.23 \mathrm{a}$ & $6.61 \mathrm{a}$ & $10.34 \mathrm{a}$ \\
\hline U. brizantha & $2.60 \mathrm{~b}$ & $35.11 \mathrm{a}$ & $9.43 \mathrm{ab}$ & $8.28 \mathrm{a}$ & $6.88 \mathrm{a}$ & $11.23 \mathrm{a}$ \\
\hline Millet & $4.49 \mathrm{a}$ & $43.83 \mathrm{a}$ & $7.10 \mathrm{ab}$ & $8.43 \mathrm{a}$ & $6.14 \mathrm{a}$ & $11.46 \mathrm{a}$ \\
\hline \multirow[t]{2}{*}{ Mean } & $3.22 \mathrm{D}$ & 39.79A & $8.66 \mathrm{BC}$ & $7.64 \mathrm{C}$ & $6.67 \mathrm{C}$ & $10.62 \mathrm{~B}$ \\
\hline & \multicolumn{6}{|c|}{ Nitrate/ammonium ratio } \\
\hline Fallow & $13.79 \mathrm{c}$ & $2.32 b$ & $4.05 b$ & $4.01 \mathrm{~b}$ & $0.36 \mathrm{~b}$ & $0.53 \mathrm{a}$ \\
\hline P. maximum & $13.81 b c$ & $2.58 \mathrm{~b}$ & $4.62 b$ & $5.39 \mathrm{a}$ & $0.47 \mathrm{ab}$ & $0.66 \mathrm{a}$ \\
\hline U. ruziziensis & $18.96 \mathrm{a}$ & $3.40 \mathrm{a}$ & $11.34 \mathrm{a}$ & $3.55 \mathrm{bc}$ & $0.60 \mathrm{ab}$ & $0.71 \mathrm{a}$ \\
\hline U. brizantha & $16.70 \mathrm{ab}$ & $3.77 \mathrm{a}$ & $7.04 \mathrm{ab}$ & $2.40 \mathrm{~cd}$ & $0.64 \mathrm{a}$ & $0.63 \mathrm{a}$ \\
\hline$\underline{\text { Millet }}$ & $8.25 \mathrm{~d}$ & $1.87 \mathrm{~b}$ & $5.71 \mathrm{ab}$ & $1.88 \mathrm{~d}$ & $0.30 \mathrm{~b}$ & $0.37 \mathrm{~b}$ \\
\hline Mean & $15.46 \mathrm{~A}$ & $3.10 \mathrm{C}$ & $8.93 \mathrm{~B}$ & $3.57 \mathrm{C}$ & $0.54 \mathrm{D}$ & $0.63 \mathrm{D}$ \\
\hline
\end{tabular}

${ }^{(1)}$ Means followed by equal letters, lowercase in the columns and uppercase in the lines, do not differ by LSD test, at 5\% probability. 
to the soil, and differed from fallow, U. ruziziensis and $U$. brizantha. As observed for nitrate, application of urea, one day after rice sowing, increased the levels of ammonium in the soil, which could be noted in the following soil samplings (7 days).

Regarding nitrate/ammonium ratio, there was no effect of desiccation timing (Table 2). However,

Table 3. Soil nitrate level $\left(\mathrm{mg} \mathrm{kg}^{-1}\right)$ at $0-10 \mathrm{~cm}$ soil depth as a function of sampling dates (days after sowing, DAS) and herbicide timing (days before sowing).

\begin{tabular}{lcccc}
\hline \multirow{2}{*}{$\begin{array}{l}\text { Sampling date } \\
\text { DAS })\end{array}$} & \multicolumn{4}{c}{ Herbicide timing (days before sowing) } \\
\cline { 2 - 5 } & 30 & 20 & 10 & 0 \\
\hline 0 & $53.49 \mathrm{~A}$ & $56.73 \mathrm{~A}$ & $39.75 \mathrm{~B}$ & $24.91 \mathrm{C}$ \\
7 & $118.97 \mathrm{~A}$ & $119.77 \mathrm{~A}$ & $114.49 \mathrm{~A}$ & $86.19 \mathrm{~B}$ \\
14 & $57.81 \mathrm{~A}$ & $57.77 \mathrm{~A}$ & $49.35 \mathrm{~A}$ & $44.79 \mathrm{~A}$ \\
21 & $29.94 \mathrm{~A}$ & $20.91 \mathrm{~B}$ & $24.94 \mathrm{AB}$ & $26.22 \mathrm{AB}$ \\
28 & $2.31 \mathrm{~B}$ & $2.31 \mathrm{~B}$ & $3.87 \mathrm{~A}$ & $4.25 \mathrm{~A}$ \\
35 & $5.48 \mathrm{~B}$ & $5.12 \mathrm{~B}$ & $6.29 \mathrm{~B}$ & $7.63 \mathrm{~A}$ \\
\hline Mean & $44.67 \mathrm{~A}$ & $43.78 \mathrm{~A}$ & $39.28 \mathrm{~B}$ & $32.31 \mathrm{C}$ \\
\hline
\end{tabular}

* Means followed by equal letters in the lines do not differ, by LSD test, at $5 \%$ probability.
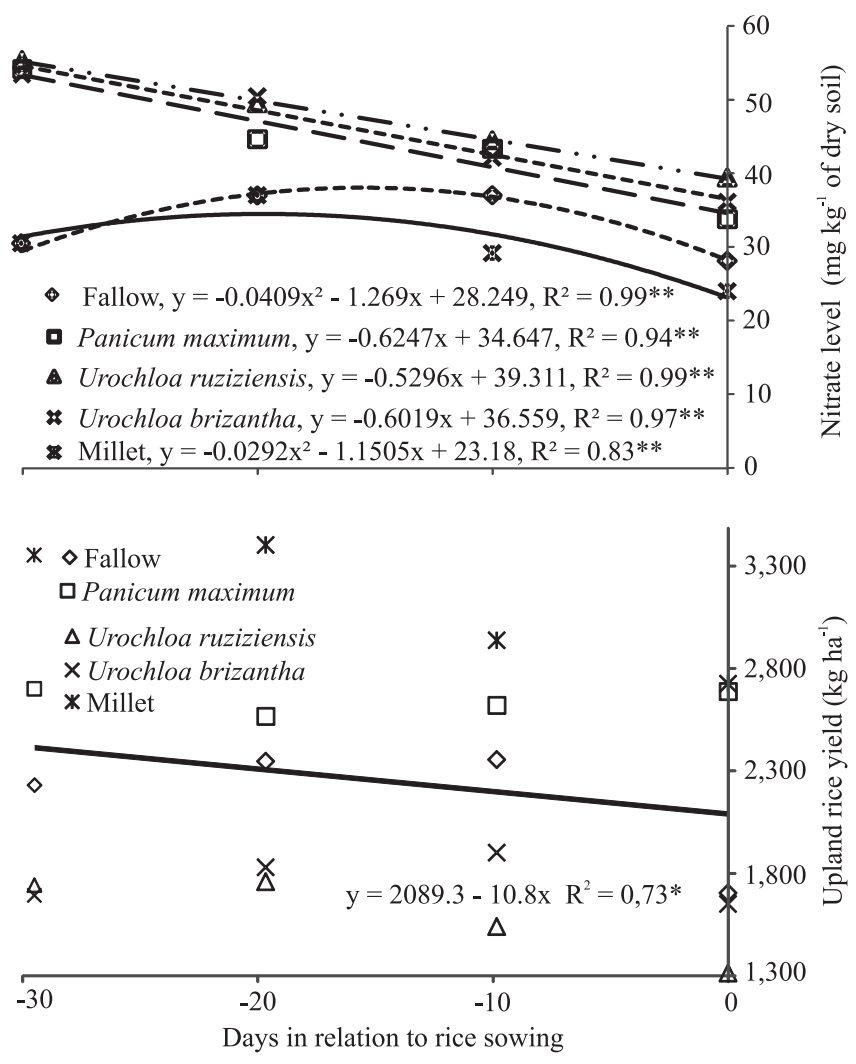

Figure 2. Nitrate concentration at $0-10 \mathrm{~cm}$ depths as a function of desiccation time of the cover crops, before rice sowing $(30,20,10$, and 0 days before sowing day). sampling dates and cover crops significantly interfered on it. Split plots under millet had the lowest ratio at the first, fourth and sixth evaluation dates, differing from all other cover crops. In the second sampling, under millet, nitrate/ammonium ratio had the lowest value, differing from $U$. ruziziensis and U. brizantha .

As to grain yield of upland rice, data fitted a linear regression (Figure 2), with higher values at earlier desiccation times. Nascente \& Crusciol (2012) reported similar results for soybean plants, which had higher grain yield when cover crop desiccation was done 10 or more days before sowing. Nascente et al. (2012) stated that upland rice has greater grain yield when $U$. ruziziensis is desiccated 30 days before rice sowing, under greenhouse conditions.

Millet as cover crop provided the highest grain yield (Table 4). Arf et al. (2001), Bordin et al. (2003), Cazetta et al. (2008) and Pacheco (2009) also obtained higher upland rice yield using millet as cover crop. This can be attributed to a better development of upland rice with low nitrate/ammonium ratio, in the first weeks of crop development (Lin et al., 2005; Li et al., 2007; Holzschuh et al., 2009; Poletto et al., 2011; Araújo et al., 2012). Millet provided the lowest amount of nitrate and the highest level of ammonium to the soil in almost all evaluations. The fact that rice plants came from a hydrophilic environment (Lin et al., 2005), where $\mathrm{N}^{-\mathrm{NH}_{4}}{ }^{+}$prevails (Schjoerring et al., 2002; Li et al., 2007), can explain this preference for low nitrate/ammonium ratio. Araújo et al. (2012) reported that upland rice plants have difficulty in metabolizing nitrate in the early development, since the production of nitrate reductase enzyme by this crop takes time to begin. This fact could explain the low initial rice development, when $\mathrm{N}_{-} \mathrm{NO}_{3}^{-}$prevails in the environment, with negative effects on rice grain yield (Holzschuh et al., 2009), as observed in treatments with $U$. brizantha, $U$. ruziziensis and P. maximum.

Table 4. Upland rice yield cultivated after cover crops at no tillage system ${ }^{(1)}$.

\begin{tabular}{lc}
\hline Cover crops & Grain yield $\left(\mathrm{kg} \mathrm{ha}^{-1}\right)$ \\
\hline Fallow & $2,159 \mathrm{bc}$ \\
Panicum maximum & $2,633 \mathrm{~b}$ \\
Urochloa ruziziensis & $1,595 \mathrm{c}$ \\
Urochloa brizantha & $1,772 \mathrm{c}$ \\
Millet & $3,100 \mathrm{a}$ \\
\hline
\end{tabular}

${ }^{(1)}$ Means followed by equal letters do not differ by LSD test, at $5 \%$ probability. 


\section{Conclusions}

1. Larger levels of nitrate in the soil are found when cover crops are desiccated earlier.

2. Cover crop species and desiccation timing can be used to change the levels and form of $\mathrm{N}$ in the soil.

3. Millet provides the lowest nitrate/ammonium ratio and the highest upland rice yield

\section{Acknowledgments}

To Embrapa, for the financial support and scholarship to the first author, and to Conselho Nacional de Desenvolvimento Científico e Tecnológico (CNPq), for the research productivity scholarship granted to the second author.

\section{References}

ARAÚJO, J.L.; FAQUIN, V.; VIEIRA, N.M.B.; OLIVEIRA, M.V.C. de; SORAES, A.A.; RORIGUES, C.R.; MESQUITA, A.C. Crescimento e produção do arroz sob diferentes proporções de nitrato e de amônio. Revista Brasileira de Ciência do Solo, v.36, p.921-930, 2012.

ARF, O.; RODRIGUES, R.A.F.; SÁ, M.E. de; CRUSCIOL, C.A.C. Resposta de cultivares de arroz de sequeiro ao preparo do solo e à irrigação por aspersão. Pesquisa Agropecuária Brasileira, v.36, p.871-879, 2001.

BOER, C.A.; ASSIS, R.L. de; SILVA, G.P.; BRAZ, A.J.B.P.; BARROSO, A.L.L.; CARGNELUTTI FILHO, A.; PIRES, F.R. Nutrient cycling in off-season cover crops on a Brazilian savanna soil. Pesquisa Agropecuária Brasileira, v.42, p.1269-1276, 2007.

BORDIN, L.; FARINELLI, R.; PENARIOL, F.G.; FORNASIERI FILHO, D. Sucessão de cultivo de feijão-arroz com doses de adubação nitrogenada após adubação verde, em semeadura direta. Bragantia, v.62, p.417-428, 2003.

BREMNER, J.M. Total nitrogen. In: BLACK, C.A. (Ed.). Methods of soil analysis. Part. 2. Chemical and microbiological properties. Madison: Soil Science Society of America, 1965. p.1149-1178. (Agronomy monograph, 9).

CARNEIRO, M.A.C.; SOUZA, E.D. de; REIS, E.F. dos; PEREIRA, H.S.; AZEVEDO, W.R. Physical, chemical and biological properties of Cerrado soil under different land use and tillage systems. Revista Brasileira de Ciência do Solo, v.33, p.147-157, 2009.

CAZETTA, D.A.; ARF, O.; BUZETTI, S.; SA, M.E.; RODRIGUES, R.A.F. Desempenho do arroz de terras altas com a aplicação de doses de nitrogênio e em sucessão às culturas de cobertura do solo em sistema de plantio direto. Bragantia, v.67, p.471-479, 2008.

D'ANDRÉA, A.F.; SILVA, M.L.N.; CURI, N.; GUILHERME, L.R.G. Carbon and nitrogen storage, and inorganic nitrogen forms in a soil under different management systems. Pesquisa Agropecuária Brasileira, v.39, p.179-186, 2004.
DABNEY, S.M.; DELGADO, J.A.; REEVES, D.W. Using winter cover crops to improve soil and water quality. Communications in Soil Science and Plant Analysis, v.32, p.1221-1250, 2001.

FAGERIA, N. K.; MOREIRA, A. The role of mineral nutrition on root growth of crop plants. Advances in Agronomy, v.110, p.251-331, 2011.

FOOD AND AGRICULTURE ORGANIZATION OF THE UNITED NATIONS. World reference base for soil resources. Rome: FAO, 1998. Available at: <http://www.fao.org/docrep/ W8594E/W8594E00.htm>. Accessed on: 13 Mar. 2012.

GINE, M.F.; BERGAMIN FILHO, H.; ZAGATO, E.A.G.; REIS, B.F. Simultaneous determination of nitrate and nitrite by flow injection analysis. Analytica Chimica Acta, v.114, p.191-197, 1980.

GRIESS, P. Bemerkungen zu der Abhandlung der H.H. Weselsky und Benedikt "Ueber einige Azoverbindungen". Berichte der Deutschen Chemischen Gesellschaft, v.12, p.426-428, 1879.

GRISSO, R.B.; HOLSHOUSER, D.; PITMAN, R. Planter/drill considerations for conservation tillage systems. 2009. Available at: <http://pubs.ext.vt.edu/442/442-457/442-457.html>. Accessed on: 22 Mar. 2012.

HOLZSCHUH, M.J.; BOHNEN, H.; ANGHINONI, I.; MEURER, E.J.; CARMONA F. de C.; COSTA, S.E.V.G. de A. Resposta do arroz irrigado ao suprimento de amônio e nitrato. Revista Brasileira de Ciência do Solo, v.33, p.1323-1331, 2009.

KLIEMANN, H.J.; BRAZ, A.J.P.B.; SILVEIRA, P.M. da. Taxas de decomposição de resíduos de espécies de cobertura em Latossolo Vermelho distroférrico. Pesquisa Agropecuária Tropical, v.36, p.21-28, 2006.

KROM, M.D. Spectrophotometric determination of ammonia: a study of a modified Berthelot reaction using salicylate and dichloroisocyanurate. Analyst, v.105, p.305-316, 1980.

LI, Y.L.; ZHANG, Y.L.; HU, J.; SHEN, Q.R. Contribution of nitrification happened in rhizospheric soil growing with different rice cultivars to N nutrition. Biology and Fertility of Soils, v.43, p.417-425, 2007.

LIN, S.; LI, J.; SATTELMACHER, B.; BRUCK, H. Response of lowland and aerobic rice to ammonium and nitrate supply during early growth stages. Journal of Plant Nutrition, v.28, p.1495-1510, 2005.

NASCENTE, A.S.; CRUSCIOL, C.A.C. Cover crops and herbicide timing management on soybean yield under no-tillage system. Pesquisa Agropecuária Brasileira, v.47, p.187-192, 2012.

NASCENTE, A.S.; GUIMARÃES, C.M.; COBUCCI, T.; CRUSCIOL, C.A.C. Brachiaria ruziziensis and herbicide on yield of upland rice. Planta Daninha, v.30, p.729-735, 2012.

NASCENTE, A.S.; KLUTHKOUSKI, J.; RABELO, R.R.; OLIVEIRA, P. de; COBUCCI, T.; CRUSCIOL, C.A.C. Produtividade do arroz de terras altas em função do manejo do solo e da época de aplicação de nitrogênio. Pesquisa Agropecuária Tropical, v.41, p.60-65, 2011.

PACHECO, L.P. Arroz de terras altas cultivado em sucessão a plantas de cobertura em sistemas de manejo do solo. 2009. 120p. Tese (Doutorado) - Universidade Federal de Goiás, Goiânia. 
PACHECO, L.P.; LEANDRO, W.M.; MACHADO, P.L.O. de A.; ASSIS, R.L. de; COBUCCI, T.; MADARI, B.E.; PETTER, F.A. Produção de fitomassa e acúmulo e liberação de nutrientes por plantas de cobertura na safrinha. Pesquisa Agropecuária Brasileira, v.46, p.17-25, 2011.

PAUL, E.A.; CLARK, F.E. Soil microbiology and biochemistry. San Diego: Academic Press, 1989. 27p.

POLETTO, N.; MUNDSTOCK, C.M.; GROHS, D.S.; MAZURANA, M. Padrão de afilhamento em arroz afetado pela presença dos íons amônio e nitrato. Bragantia, v.70, p.96-103, 2011.

PRASAD, R. Aerobic rice systems. Advances in Agronomy, v.111, p.207-236, 2011.

QU,Y.; PING, M.; HONGLIANG, Z.; CHEN, C.Y.; GAO, Y.; TIAN, Y.; WEN, F.; LI, Z. Mapping QTLs of root morphological traits at different growth stages in rice. Genetica, v.133, p.187-200, 2008 .
SCHJOERRING, J.K.; HUSTED, S.; MACK, G.; MATTSSON, $\mathrm{M}$. The regulation of ammonium translocation in plants. Journal of Experimental Botany, v.53, p.883-890, 2002.

TAO, H.B.; BRUECK, H.; DITTERT, K.; KREYE, C.; LIN, S.; SATTELMACHER, B. Growth and yield formation of rice (Oryza sativa L.) in the water-saving ground cover rice production system (GCRPS). Field Crops Research, v.95, p.1-12, 2006.

THOMAS, R.J.; ASAKAWA, N.M. Decomposition of leaf litter from tropical forage grasses and legumes. Soil Biology and Biochemistry, v.25, p.1351-1361, 1993.

TORRES, J.L.R.; PEREIRA, M.G.; FABIAN, A.J. Produção de fitomassa por plantas de cobertura e mineralização de seus resíduos em plantio direto. Pesquisa Agropecuária Brasileira, v.43, p.421-428, 2008.

TORRES, J.L.R.; PEREIRA, M.G.; ANDRIOLI, I.; POLIDORO, J.C.; FABIAN, A.J. Decomposição e liberação de nitrogênio de resíduos culturais de plantas de cobertura em um solo de cerrado. Revista Brasileira de Ciência do Solo, v.29, p.609-618, 2005.

Received on April 8, 2012 and accepted on November 12, 2012 